TES L A | VOL. 21| NO. 1 | MARET 2019 |

\title{
Perancangan Fidget Device Berbasis Internet Of Things
}

\author{
Nova Eka Budiyanta ${ }^{1}$, Mega Cynthia Wishnu ${ }^{1}$, Dolly Ramli Wohon ${ }^{1}$, Lukas $^{1}$
}

\begin{abstract}
Increasing stress level among the people is rising a concern. Fidget devices are proposed as a way to help relieve stress. They are easy to use and can be carried everywhere. Two of most commonly used fidget devices are fidget spinner and fidget cube. These fidget devices are believed to cope with anxiety so that users can focus their nervous energy on fidget devices. In this research, the fidget device to be discussed is the fidget cube, since it is considered as safer and has various button than the fidget spinner. Not only stress relievers, IoT-based fidget cube also has the ability to send data to a web server. It aims to see a trend or data about the user's behavior, which buttons are often used by users and the frequency of using fidget cube in daily life. This data can later be used in other scientific fields.
\end{abstract}

KEYWORDS: fidget device, fidget cube, stress, internet-of-things

ABSTRAK: Tingkat stress di dunia mengalami kenaikan dari tahun ke tahun. Oleh karena itu, teknologi semakin berkembang menciptakan alat pengurang stres yang mudah digunakan dan dibawa kemanapun. Salah satu alat pengurang stres adalah fidget devices. Saat ini, ada dua bentuk fidget devices yang umum digunakan, yaitu fidget spinner dan fidget cube. Kedua fidget devices ini dipercaya untuk mengatasi kegelisahan sehingga pengguna dapat memusatkan kegelisahannya ke fidget devices. Dalam perancangan kali ini, fidget device yang akan dibahas adalah fidget cube karena fidget cube dirasa lebih aman dan lebih bervariasi jika dibandingkan fidget spinner. Tak hanya penghilang stres, fidget cube berbasis IoT juga memiliki kemampuan untuk mengirim data ke web server. Hal ini bertujuan untuk melihat suatu trend atau data mengenai perilaku si pengguna, tombol mana saja yang sering digunakan oleh pengguna dan frekuensi penggunaan fidget cube pada kehidupan sehari-hari. Data ini nantinya dapat digunakan dalam bidang keilmuan lainnya.

KATA KUNCI: fidget device, fidget cube, stres, internet-of-things

\section{PENDAHULUAN}

$\mathrm{T}$ ingkat stress di dunia mengalami kenaikan dari tahun ke tahun. Seperti yang diungkapkan oleh Cohen bahwa terjadi peningkatan stres dari waktu ke waktu . Cohen menambahkan bahwa tingkat stres orang berusia 30 tahun lebih rendah dari orang yang berusia 20 tahun, serta orang yang berusia 40 tahun mempunyai tingkat stres yang lebih rendah dari orang yang berusia 30 tahun. Secara tidak langsung dapat digambarkan dari pernyataan tersebut bahwa tingkat stres antar generasi berbeda dan terus meningkat.

Untuk mengatasi kadar stres yang dialami, tidak sedikit masyarakat menggunakan fidget devices. Salah satu fidget devices yang populer adalah fidget spinner. Fidget spinner banyak digunakan masyarakat di tengah - tengah kesibukan karena dinilai dapat membantu redakan stres dan meningkatkan fokus. Seperti yang disampaikan oleh Ratih bahwa penggunaan fidget spinner dapat membantu seseorang memandang sesuatu berulang - ulang secara terus menerus pada satu titik dan mengakibatkan seseorang dapat terokupasi pada situasi tersebut, sehingga stres dapat diredakan

Meskipun fidget spinner dinilai dapat membantu meredakan stres, fidget spinner juga memiliki kelemahan yang dapat membahayakan pengguna. Seperti yang dinyatakan Ismarlina bahwa fidget spinner nyaris membuat balita kehilangan salah satu jari dikarenakan terjepit dalam salah satu lubang bearing pada fidget spinner. Hal tersebut mengakibatkan beberapa orang beranggapan bahwa penggunaan fidget spinner berbahaya.

Lain dari fidget spinner, fidget devices yang dinilai dapat menurunkan kadar stres seseorang adalah fidget cube. Produk yang didesain dua bersaudara, Matthew dan Mark McLahan dinilai dapat menjadi alternatif fidget device diantara fidget devices yang lain. Seperti yang diungkapkan oleh Matthew dan Mark McLahan (2016) bahwa mereka percaya diperlukan perubahan dalam cara mengatasi gelisah .

Meskipun penggunaan fidget cube mulai merambah pengguna, fidget cube tetap hanya saja alat yang dapat meredakan kadar stres tanpa kita tahu pasti penurunan dan peningkatan kadar stres tiap pengguna dari penggunaan hari demi hari. Meskipun seseorang merasa bahwa tingkat stres dapat menurun setelah menggunakan fidget devices, seseorang haruslah tahu peningkatan dan penurununan kadar stres setiap hari, sehingga dapat memonitor dan mengevaluasi diri akan stres yang dialami. Untuk itu dibutuhkan fidget devices yang dapat memberikan data untuk mengetahui peningkatan dan penurunan kadar stres seseorang. Berdasarkan latar belakang masalah yang ada, penelitian ini dibatasi pada perancangan fidget devices yang dapat mengirimkan data penggunaan berbasis Internet of Things.

\section{FIDGET DEVICES / PEMINTAL GELISAH}

Perangkat fidget (fidget devices) atau yang biasa disebut pemintal gelisah muncul untuk mengatasi kegelisahan yang dapat menyebabkan stres. Beberapa cara menangani kegelisahan adalah dengan melakukan manipulasi objek dan dilakukan secara berulang - ulang sehingga tanpa disadari seseorang akan melakukan hal yang sama ketika mengalami kegelisahan. Terdapat beberapa perangkat fidget yang di antaranya adalah Fidget Spinner, Fidget Cube, Slime, Stressball. Dengan adanya perangkat fidget diharapkan dapat membantu seseorang menurunkan kadar stresnya.

\footnotetext{
${ }^{1}$ Program Studi Teknik Elektro Universitas Katolik Atma Jaya
} 


\section{FIDGET FINGER BERBASIS IOT}

Perangkat fidget dalam penelitian ini dimaksudkan untuk membantu merekam data penggunaan perangkat fidget. Perangkat fidget didesain menggunakan beberapa jenis tombol yang sekaligus dijadikan sebagai data masukan untuk dapat dikirim ke server. Diagram blok dan skematik dari perangkat fidget pada penelitian ini dapat dilihat pada Gambar 1 dan Gambar 2. Terdapat beberapa jenis tombol yang digunakan dalam penelitian ini. Jenis tombol ditentukan berdasarkan fungsi penggunaannya. Berikut merupakan jenis - jenis tombol yang digunakan pada perangkat fidget:
1. Joystick
2. $\quad$ Single Pole Single Throw (SPST)
3. $\quad$ Single Pole Double Throw (SPDT)
4. $\quad$ Double Pole Double Throw (DPDT)
5. Volume Wheel

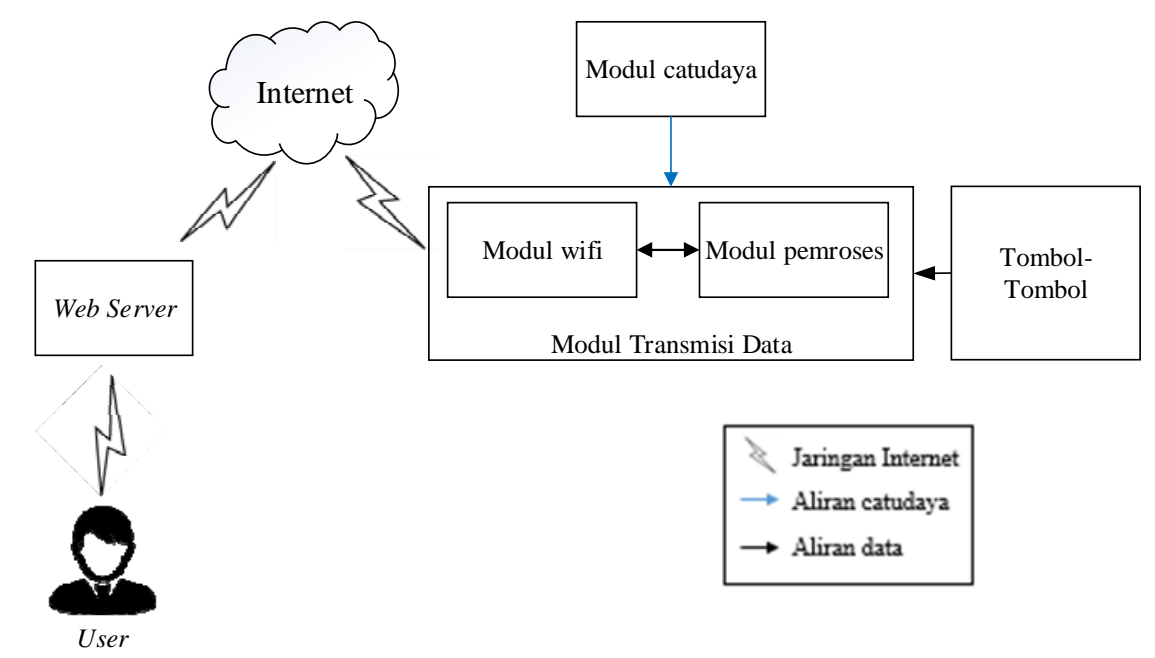

- Gambar 1. Desain blok diagram perangkat fidget cube berbasis Internet of Things

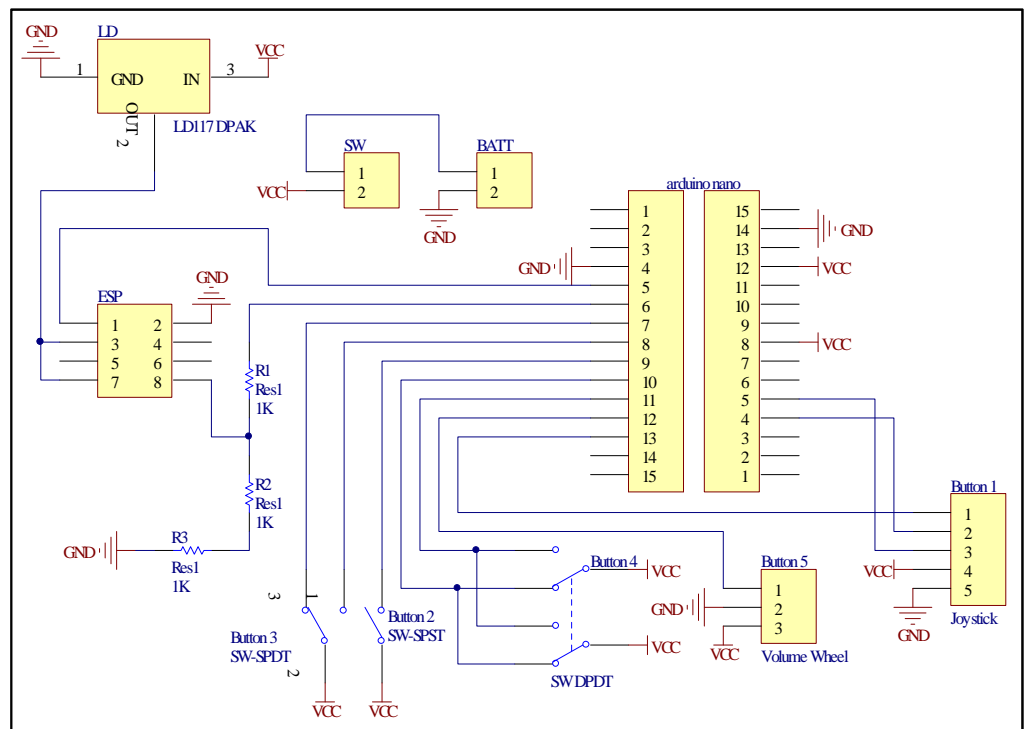

- Gambar 2. Skematik fidget cube

Untuk mendukung tombol sebagai pemberi sinyal masukan, perangkat dilengkapi dengan mikrokontroler pengolah paket sinyal masukan sebelum dikirim ke server. Mikrokontroler adalah sebuah alat pengendali berukuran mikro (sangat kecil) yang dikemas dalam bentuk chip. Komponen dasar mikrokontroler dapat dilihat pada Gambar 3. 


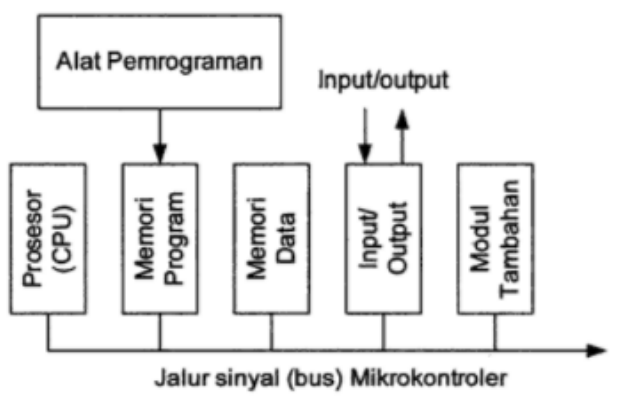

Gambar 3. Komponen Dasar Mikrokontroler [6].

Prosesor (CPU) merupakan pemroses utama dalam mikrokontroler. Prosesor mengeksekusi instruksi yang dibaca dari memori program. Memori program berfungsi untuk menyimpan instruksi yang dibaca oleh prosesor. Sedangkan memori data berfungsi untuk menyimpan data dan variabel. Alat pemrograman adalah alat yang digunakan untuk memasukkan program atau perintah ke dalam chip mikrokontroler. Input/output merupakan perangkat yang dapat dihubungkan dengan perangkat luar. Modul tambahan berisikan berbagai fungsi tambahan yang disediakan oleh mikrokontroler. Tiap mikrokontroler memiliki modul tambahan yang berbeda, misalnya Counter/Timer, Interupt dan lain-lain.

Arduino Nano digunakan sebagai mikrokontroler dalam perancangan fidget finger. Arduino Nano dipilih karena telah tertanam mikrokontroler ATMega328P di dalamnya. Arduino Nano bekerja pada tegangan 5V dan dilengkapi port mini usb untuk mendukung pemrograman.

Modul mikrokontroler Arduino Nano memiliki clock frequency sebesar $16 \mathrm{MHz}$, memiliki 30 pin yang di antaranya adalah 8 pin analog dan 14 pin digital serta 2 pin sebagai tegangan masukan. Pin tegangan masukan tersebut adalah pin $+5 \mathrm{~V}$ dan VIN.

Apabila tegangan masukan yang digunakan adalah $5 \mathrm{~V}$, maka sumber tegangan dapat langsung dihubungkan ke pin $+5 \mathrm{~V}$. Namun, apabila tegangan masukan yang digunakan berkisar antara $6 \mathrm{~V}$ hingga $18 \mathrm{~V}$, maka sumber tegangan harus dihubungkan ke pin VIN. Arduino Nano memiliki regulator $5 \mathrm{~V}$ yang dihubungkan ke pin VIN, sehingga ketika sumber tegangan diatas $5 \mathrm{~V}$, tegangan akan lebih dulu diturunkan menjadi $5 \mathrm{~V}$. Penampakan modul mikrokontroler Arduino Nano dapat dilihat pada Gambar 4.

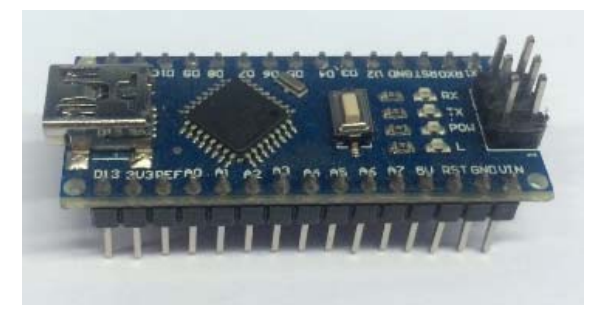

- Gambar 4. Mikrokontroler Arduino Nano

\section{BAHASA PEMROGRAMAN ARDUINO DAN ARDUINO IDE}

Bahasa pemrograman arduino berbasis bahasa $\mathrm{C} / \mathrm{C}++$. Hanya saja, beberapa format penulisan atau syntax yang digunakan sedikit berbeda. Namun, syntax yang berbeda tersebut akan diubah ke standar bahasa $\mathrm{C} / \mathrm{C}++$ oleh Arduino IDE. Arduino IDE merupakan compiler yang digunakan untuk memprogram mikrokontroler Arduino. Arduino tidak dapat diprogram menggunakan compiler lain selain Arduino IDE. Tampilan Arduino IDE dapat dilihat pada Gambar 5.

Struktur program Arduino memiliki dua fungsi utama, yaitu: void setup () dan void loop (). void setup () hanya dijalankan satu kali di awal program. void setup () biasanya berisikan inisialisasi awal program. Sedangkan void loop () merupakan fungsi dimana program utama ditulis dan program tersebut akan terus dijalankan. Selain dua fungsi utama tersebut, semua library dan pendefinisian yang diperlukan dapat ditulis di atas void setup (). 


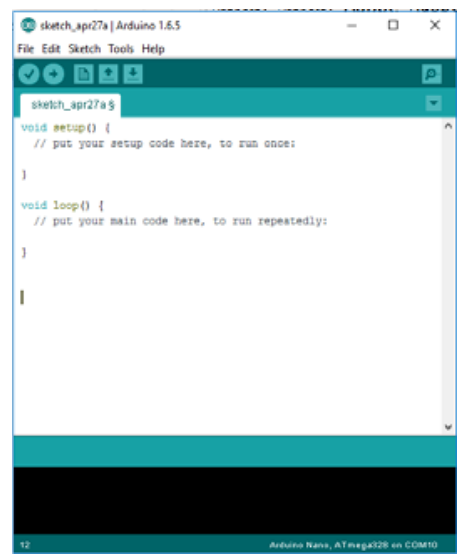

- Gambar 5. Arduino IDE

KONEKTIVITAS

Selain perangkat untuk mendukung pemrosesan data, terdapat juga perangkat yang digunakan untuk komunikasi dan mendukung pengiriman data ke database server. Perangkat komunikasi salam penelitian ini adalah Wi-Fi. Wi-Fi merupakan sekumpulan standar yang digunakan untuk jaringan lokal nirkabel yang didasari pada spesifikasi IEEE 802.11 [7]. Saat ini, terdapat empat standar Wi-Fi, yaitu: 802.11b, 802.11a, 802.11g, 802.11n. Perbedaan standar Wi-Fi tersebut dapat dilihat pada Tabel 1.

Tabel 1. Perbedaan standar Wi-Fi

\begin{tabular}{|l|l|l|l|}
\hline Standar & Kecepatan & Frekuensi Band & Seri Kompatibilitas \\
\hline $802.11 \mathrm{~b}$ & $11 \mathrm{Mb} / \mathrm{s}$ & $2,4 \mathrm{GHz}$ & $\mathrm{b}$ \\
\hline $802.11 \mathrm{a}$ & $54 \mathrm{Mb} / \mathrm{s}$ & $5 \mathrm{GHz}$ & $\mathrm{a}$ \\
\hline $802.11 \mathrm{~g}$ & $54 \mathrm{Mb} / \mathrm{s}$ & $2,4 \mathrm{GHz}$ & $\mathrm{b}, \mathrm{g}$ \\
\hline $802.11 \mathrm{n}$ & $100 \mathrm{Mb} / \mathrm{s}$ & $2,4 \mathrm{GHz}$ & $\mathrm{a}, \mathrm{b}, \mathrm{g}$ \\
\hline
\end{tabular}

Modul Wi-Fi yang digunakan dalam penelitian ini adalah ESP8266-01. Modul Wi-Fi ESP8266-01 memiliki 8 pin, konfigurasi pin tersebut dapat dilihat pada Gambar 6. Pin ground dihubungkan ke ground sistem dan pin VCC serta pin CH_PD dihubungkan ke sumber tegangan 3,3 V. Pin TX dihubungkan ke pin RX mikrokontroler dan pin RX dihubungkan ke pin TX mikrokontroler. Sedangkan tiga pin lainnya dibiarkan tidak terhubung. ESP8266-01 memiliki 2 LED indikator berwarna merah dan biru. LED merah menandakan bahwa ESP8266-01 telah aktif sedangkan LED biru menandakan sedang terjadinya komunikasi data. Modul Wi-Fi ESP8266-01 dapat bekerja pada tegangan 3,3V. Modul Wi-Fi ESP8266-01 dapat dilihat pada Gambar 7.

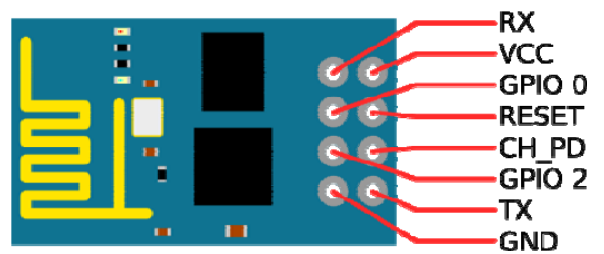

Gambar 6. Konfigurasi Pin ESP8266-01 [8]

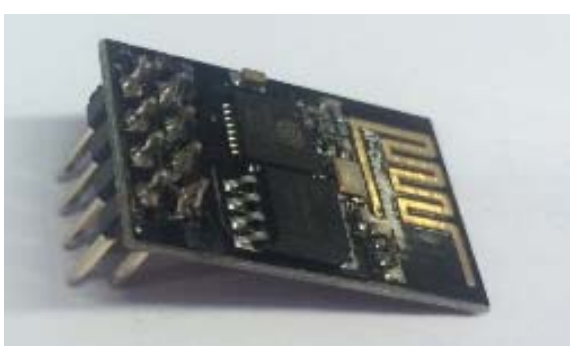


- Gambar 7. Modul Wi-Fi ESP8266 - 01

\section{POWER SUPPLY}

Untuk mendukung supply tegangan pada perangkat, Baterai Lithium Polymer (Li-Po) digunakan dalam penelitian ini. Baterai Li-Po termasuk jenis baterai yang sering digunakan pada banyak perangkat elektronik. Tidak jarang baterai Li-Po menjadi pilihan bagi konsumen yang memerlukan daya besar dan dalam jangka waktu yang lama [9]. Baterai Lithium Polymer (Li-Po) yang digunakan dalam perancangan adalah baterai 3,7 V $400 \mathrm{mAh}$. Ukuran baterai ini cukup kecil, yaitu 38 x 18 x $6 \mathrm{~mm}$ dengan berat 10 gram. Apabila di-charge penuh, baterai bisa menyimpan tegangan hingga 4,2 V. Baterai Li-Po 3,7 V 400 mAh dapat dilihat pada Gambar 8.

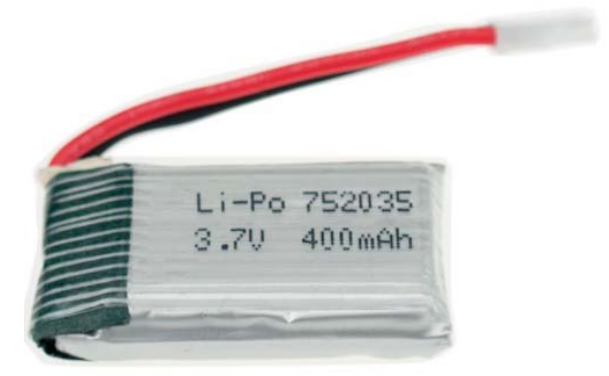

- Gambar 8. Baterai Li-Po 3,7 V 400 mAh

Baterai pada perangkat ini dilengkapi dengan modul TP4056 sebagai charger. Tegangan kerja pada modul charger TP4056 adalah 4,5V hingga 5,5V. Modul charger TP4056 memiliki dua LED indikator, yaitu LED berwarna merah yang menandakan mode pengisian baterai / charging dan LED berwarna hijau yang menandakan mode penuh / full charge. Modul charger TP4056 dilengkapi dengan proteksi, jadi apabila baterai sudah terisi penuh, maka catu daya untuk rangkaian langsung di-supply dari tegangan $5 \mathrm{~V}$ yang berasal dari modul charger. Penampakan modul charger TP4056 dapat dilihat pada Gambar 9.

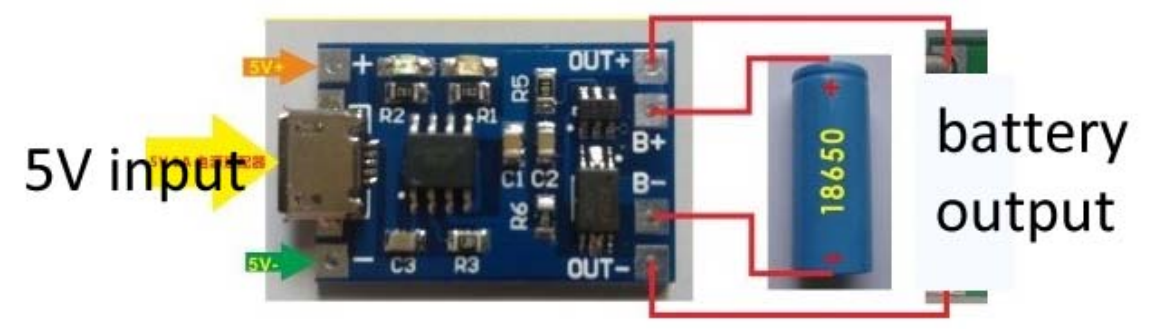

Gambar 9. Modul Charger TP4056 [10]

Selain penggunaan Baterai Li-Po dan Modul Charger, diperlukan penurun tegangan untuk mencatu rangkaian. Penurun tegangan yang dipakai pada perangkat ini adalah LD1117. Tegangan masukan pada regulator LD1117 dapat mencapai 18V, namun tegangan masukan yang disarankan maksimal 15V. LD1117 dapat digunakan untuk menghasilkan tegangan keluaran $1,2 \mathrm{~V}, 1,8 \mathrm{~V}, 2,5 \mathrm{~V}$, dan $5 \mathrm{~V}$. Contoh skematik penurunan tegangan 1,2V dapat dilihat pada Gambar 10.

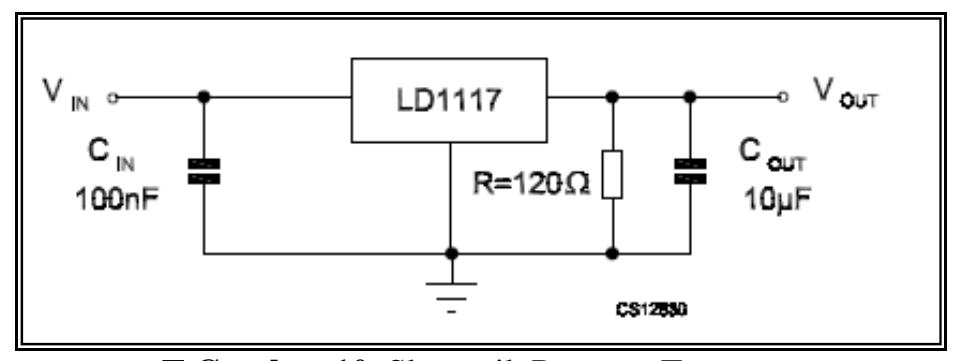

- Gambar 10. Skematik Penurun Tegangan

\section{DATABASE}

Terlepas dari rangkaian perangkat, diperlukan rancangan database untuk menampung rekam data dari perangkat. Connoly mengemukakan bahwa database atau basis data merupakan suatu kumpulan koleksi data - 
data yang berhubungan satu dengan yang lain secara logika dan dirancang guna memenuhi kebutuhan informasi [11]. Istilah umum yang sering digunakan dalam database dapat dilihat pada Tabel 2.

- Tabel 2. Istilah Umum yang Sering Digunakan dalam Database

\begin{tabular}{|l|l|l|}
\hline & Istilah & Pengertian \\
\hline 1 & Field & Sekelompok kecil kata dan atau deret angka. \\
\hline 2 & Record & Kumpulan dari field yang berhubungan secara logika. \\
\hline 3 & File & Kumpulan dari record yang berhubungan secara logika. \\
\hline 4 & Entity & $\begin{array}{l}\text { Komponen atau variabel yang berhubungan dengan data } \\
\text { yang disimpan. }\end{array}$ \\
\hline 5 & Attribute & $\begin{array}{l}\text { Karakteristik yang berfungsi untuk menjelaskan suatu } \\
\text { entity. }\end{array}$ \\
\hline 6 & $\begin{array}{l}\text { Primary } \\
\text { Key }\end{array}$ & $\begin{array}{l}\text { Field yang mempunyai nilai unik dan tidak sama antara } \\
\text { suatu record dengan record yang lain. }\end{array}$ \\
\hline 7 & $\begin{array}{l}\text { Foreign } \\
\text { Key }\end{array}$ & $\begin{array}{l}\text { Field yang mempunyai nilai tertentu dan berguna untuk } \\
\text { menjadi penghubung antar primary key yang berada } \\
\text { pada table yang berbeda. }\end{array}$ \\
\hline
\end{tabular}

Database pada penelitian ini adalah Database MySQL. Database MySQL merupakan sebuah database berbasis Relational Database Management System (RDBMS). Database MySql dijalankan pada aplikasi Phpmyadmin yang merupakan aplikasi berbasis web. Secara garis besar, database MySql terdiri dari nama database, tabel, field dan record. Record adalah data yang isinya merupakan satu kesatuan sedangkan field adalah sub bagian dari record [12]. Untuk lebih jelasnya, tampilan database MySql dapat dilihat pada Gambar 11.

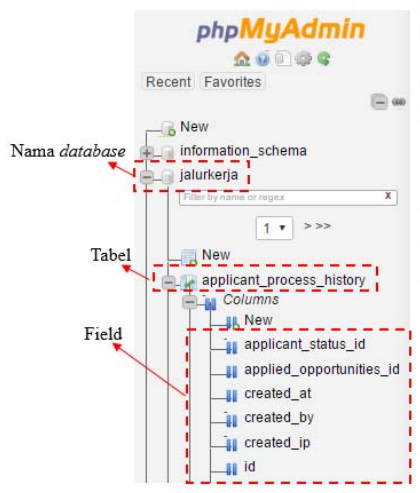

(a)

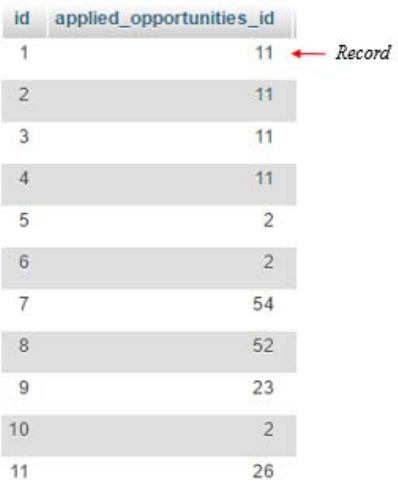

(b)

- Gambar 11 (a) Tampilan Database MySQL (b) Record Database

MySql menggunakan bahasa Structured Query Language (SQL), perintah-perintah dalam MySql disebut sebagai query. Syntax query tersebut digunakan untuk memanipulasi data, yaitu untuk menampilkan data (Select), menambah data baru (Insert), mengubah data lama dengan data yang baru (Update) dan menghapus data (Delete).

Bahasa yang digunakan pada webserver dalam penelitian ini adalah Hypertext Preprocessor (PHP). PHP merupakan sebuah bahasa pemrograman scripting untuk membuat halaman web yang dinamis. Website yang dibuat menggunakan PHP memerlukan software bernama webserver tempat pemrosesan kode PHP. Saat ini, pengguna PHP sudah digunakan pada lebih dari 20 juta website yang dijalankan dari lebih dari 1 juta server [13].

PHP banyak digunakan dalam pengembangan website karena bersifat open source dan dapat dijalankan diberbagai sistem operasi, misalnya Windows dan Linux. PHP juga mendukung banyak database dan aman karena skrip PHP tidak bisa dilihat melalui website. Cara penulisan skrip PHP adalah dengan melalui text editor seperti Notepad++ atau PhpDesigner dengan ekstensi file ‘.php'. Skrip PHP ditulis di antara tag ‘<?php' dan '?>’.

Komponen penting lainnya dari PHP adalah metode pengiriman data. Ada dua metode pengiriman data yaitu GET dan POST. GET adalah metode yang akan menampilkan data yang dikirim pada url sedangkan POST adalah metode yang tidak akan menampilkan atau menyembunyikan data yang dikirim. Penggunaan GET biasanya diterapkan pada mesin pencarian agar pengguna atau pengunjung website dapat membagikan hasil pencarian tersebut dengan meng-copy url, sedangkan penggunaan POST biasanya digunakan untuk pengisian data pada sebuah formulir sehingga data tersebut tidak ditampilkan dan bersifat rahasia. 
Syntax mysql_connect adalah syntax untuk mengkoneksikan program PHP dengan database MySql. \$hostname berisikan informasi mengenai server atau lokasi database, \$username dan \$password berisikan tentang username dan password yang digunakan untuk mengakses database tersebut.

Syntax mysql_select_db adalah syntax untuk menunjuk nama database yang digunakan. Sedangkan mysql_error adalah syntax untuk memberi tahu user apabila terjadi kesalahan dalam proses koneksi.

Syntax mysql_query adalah untuk menerjemahkan string yang ada pada variabel \$sql dan mengeksekusi query atau perintah SQL tersebut. Syntax mysql_num_rows dan mysql_fetch_array digunakan untuk menghitung jumlah record dan mengambil data-data dari tabel dan nama database yang dituju. Syntax mysql_close adalah untuk menutup atau mengakhiri koneksi ke database. Beberapa Syntax yang sering digunakan dapat dilihat pada Gambar 12.

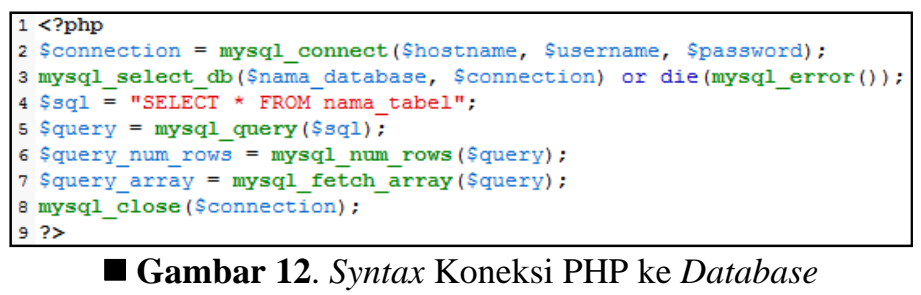

Apache merupakan aplikasi yang berfungsi sebagai web server, yaitu tempat menyimpan file-file php dan file-file lainnya yang diperlukan website [14]. Apache merupakan kumpulan dari PHP server, FTP server, SQL server dan mail server. Apache dapat dijalankan di sistem operasi baik di Windows, Linux, Unix, dan lain sebagainya.

Kelebihan web server Apache jika dibandingkan dengan web server lainnya adalah Apache termasuk ke dalam freeware atau aplikasi gratis. Selain itu, instalasi dan konfigurasi Apache juga mudah serta dapat merespon web client dengan cepat. Keunikan Apache lainnya adalah web server ini akan otomatis menjalankan halaman index pada halaman utama jika pengguna mengakses web client. Web server ini juga dapat berkomunikasi dengan client browsernya secara otomatis [15].

\section{KESIMPULAN}

Perangkat pemintal gelisah menarik untuk diteliti lebih lanjut guna mengetahui kadar stres seseorang. Untuk itu, diperlukan prototype alat dari desain berangkat yang telah dibahas pada paper ini. Penelitian ini tidak berakhir sampai disini karena diperlukan prototype nyata dan pengujian langsung terhadap alat. Selain pengujian pada alat, tidak kalah penting juga adanya peluang kolaborasi penelitian dengan berbagai disiplin ilmu untuk mewujudkan rekam data penggunaan alat sehingga dapat ditemukan faktor yang mempengaruhi dan solusi untuk mengatasi kadar stres masyarakat yang semakin meningkat.

\section{DAFTAR PUSTAKA}

[1]. Sheldon Cohen. Tingkat Stres Naik Dari Tahun ke Tahun Sejak 1983. 2012. Internet : https://health.detik.com/berita-detikhealth/d-1942486/tingkat-stres-naik-dari-tahun-ke-tahun-sejak-1983. [6 Nov 2018]

[2]. Ratih Zulhaqqi. Fidget Spinner Disebut Bisa Redakan Stres, Ini Tanggapan Psikolog. 2017. Internet : https://health.detik.com/berita-detikhealth/d-3496715/fidget-spinner-disebut-bisa-redakan-stres-initanggapan-psikolog. [6 Nov 2018]

[3]. Ismarlina Mokodompit. Fidget Spinner nyaris membuat balita ini kehilangan jarinya. 2017. Internet: https://www.brilio.net/duh/fidget-spinner-nyaris-membuat-balita-ini-kehilangan-jarinya-1706119.html . [6 Nov 2018]

[4]. Matthew, Mark McLahan. How The Fidget Cube Raised \$6.4 Million And Entered Kickstarter's Top 10 Most Funded Projects. 2016. Internet: https://www.forbes.com/sites/zarastone /2016/10/24/how-the-fidgetraised-6-4million-on-kickstarter/\#691cf5a272ab . [6 Nov 2018]

[5]. Cohen, E. J., Bravi R., Minciacchi D., The effect of fidget spinners on fine motor control. www.nature.com/scientificreports.Open Access Journal. 2018.

[6]. D. Artanto. Merakit PLC dengan Mikrokontroler. Jakarta: Elex Media Komputindo. 2009.

[7]. Wahana Komputer, Tip Jitu Optimasi Jaringan Wi-Fi. Yogyakarta: Penerbit Andi. 2010.

[8]. Forum Arduino. Connect to ESP8266 ONLY using Arduino Uno. 2014. Internet: http://forum.arduino.cc/index.php?topic=283043.0. [6 Nov 2018]

[9]. Novanky, Rezadita. Sistem Alat Pengisian Baterai Lithium - Polymer Menggunakan Pengontrol CN3063. UGM Yogyakarta. 2014.

[10]. Tokopedia, TP4056 Lithium Charger Module with Battery Protection. Internet: https://www.tokopedia.com/pielectronics/tp4056-lithium-charger-module-with-battery-protection. 
[11]. Connolly, Thomas, Carolyn Begg. Database Systems : A Practical Approach to Design, Implementation, and Management. Sixth Edition. England :Pearson Education, Ltd. 2015.

[12]. Anhar. Panduan Menguasai PHP \& MySQL Secara Otodidak. Jakarta: Mediakita, 2010, p.45.

[13]. A. Zaki dan Smitdev Community. 36 Menit Belajar Komputer: PHP dan MySQL. Jakarta: Elex Media Komputindo. 2008.

[14]. R. Abdulloh. Easy \& Simple Web Programming. Jakarta: Elex Media Computindo. 2016.

[15]. E. V. Haryanto. Jaringan Komputer. Yogyakarta: Andi. 2012. 